\title{
Analysis on knowledge level of recommended plant protection technologies in areca nut (Areca catechu) cultivation in Salem district of Tamil Nadu
}

\section{Mohanraj*}

Department of Agricultural Extension and Rural Sociology, Tamil Nadu Agricultural University, Coimbatore - 641003 (Tamil Nadu), India

\section{R. Velusamy}

Department of Agricultural Extension and Rural Sociology, Agricultural College and Research Institute, TNAU, Madurai - 625104 (Tamil Nadu), India

\section{K. Prabakaran}

Department of Agricultural Economics, Agricultural College and Research Institute, TNAU, Madurai - 625104 (Tamil Nadu), India

\author{
A. Beaulah \\ Department of Horticulture, Agricultural College and Research Institute, TNAU, \\ Madurai - 625104 (Tamil Nadu), India \\ *Corresponding author. Email: mohanrajhort@gmail.com
}

\section{Article Info}

https://doi.org/10.31018/

jans.v13iSI.2808

Received: March 22, 2021

Revised: May 14, 2021

Accepted: June 3, 2021

\section{How to Cite}

Mohanraj, V. et al. (2021). Analysis on knowledge level of recommended plant protection technologies in areca nut (Areca catechu) cultivation in Salem district of Tamil Nadu. Journal of Applied and Natural Science, 13 (SI), 105 - 109. https:// doi.org/10.31018/jans.v13iSI.2808

\begin{abstract}
Areca nut (Areca catechu) is one of the important cash crops in India. India ranks first in terms of area and production of areca nut and accounts of 54.07 per cent of its world production. The harvesting of nuts commence on the Tamil month of 'Thai' (MidJanuary to Mid-February) and spread over six months in carrying out the post-harvest practices and marketing of nuts. This study was purposively conducted in Salem district 2018-2019 and occupies first position in area (2,421 hectares) of areca nut in Tamil Nadu. The Peddanackenpalyam, Valapddy, Gengavalli and Attur blocks were selected based on the 87.28 per cent of the area under areca nut in this district with a sample size of 120 areca nut farmers selected by using a proportionate random sampling technique. Most of the respondents (80.00 per cent) had knowledge level of medium to high level of knowledge on the recommended plant protection technologies in areca nut cultivation. It was mainly due to the medium to the high level of information seeking behaviour and social participation. The study revealed that the areca nut growers differed widely in their social characteristics. Most of the respondents had a medium to a high level of knowledge on recommended technologies in areca nut cultivation. This finding stressed the importance of formulating different extension strategies for different audiences by the change agency system.
\end{abstract}

Keywords: Areca nut, Disorder, Knowledge level, Pest and disease, Plant-protection

\section{INTRODUCTION}

Areca nut (Areca catechu) is one of the important cash crops in India and it is noted from the pre-vedic period, areca nut is extensively used in Hindu religious rites of birth, marriage, nuptial and also offered to gods for veneration in the form of tamboola it also offered to guests to mark their hospitality. And also Indian Ayurveda text refers to areca nut as traditional medicine (Krishisewa, 2017). In India, it is widely used for chewing and masti- cation with betel leaves. The alkaloids extracted from the nuts have common medicinal properties such as astringent, antihelmintic, narcotic and vermifuge. India ranks first in terms of both area and production of areca nut and also accounts for 54.07 per cent of its world production (Food and Agriculture Organization, 2017). The major areca nut growing countries in the world are India, China, Myanmar, Indonesia, Thailand and Bangladesh. The major states growing areca nut was Karnataka, Kerala, Assam, Meghalaya, West Bengal, Mizo- 
ram and Tamilnadu. In Tamilnadu total area under areca nut was 6,884 ha. in this Salem district constitutes 35 per cent of the area under areca nut cultivation.

A report on "co-operative marketing to help areca nut farmers in Salem" indicated that the quantity of nuts harvested from the trees dropped to 50 per cent due to drought in that area (Ananth, 2016). The farmers in these areas started to replant the areca nut in the farms which are affected by drought. For these reasons, the study was conducted in Salem district to know about the farmers practicing the recommended technologies and their practices for drought mitigation activities. More than 30,000 farm workers, including women, also engaged directly or indirectly in the harvesting and processing of nuts. The harvesting of nuts commence on the Tamil month of 'Thai' (Mid-January to Mid-February) and spread over six months in carrying out the postharvest practices and marketing of nuts. The aim of the present study was to find out the knowledge level of recommended protection technologies of the farmers in areca nut cultivation.

\section{MATERIALS AND METHODS}

This study was purposively conducted in Salem district of Tamil Nadu. This district occupies first position in area $(2,421$ hectares) of areca nut in Tamil Nadu. Salem district consisted of 20 blocks, from this Peddanackenpalyam, Valapady, Gengavalli and Attur blocks were selected based on the 87.28 per cent of area under areca nut in this district. Fig. 1 shows that visual representation of study area selection. The total sample size of 120 areca nut farmers was selected by using a proportionate random sampling technique and given in Table 1. The formula used is as follows:

$\mathrm{ni}=[\mathrm{Ni} / \mathrm{N}] \times \mathrm{n}$

Where,

$\mathrm{Ni}=$ number of respondents to be selected from $\mathrm{i}^{\text {th }}$ block.

$\mathrm{Ni}=$ total number of respondents in the $\mathrm{i}^{\text {th }}$ block.

$\mathrm{N}=$ total number of respondents in the four blocks.

$\mathrm{n}=$ sample size.

The teacher-made knowledge test was employed

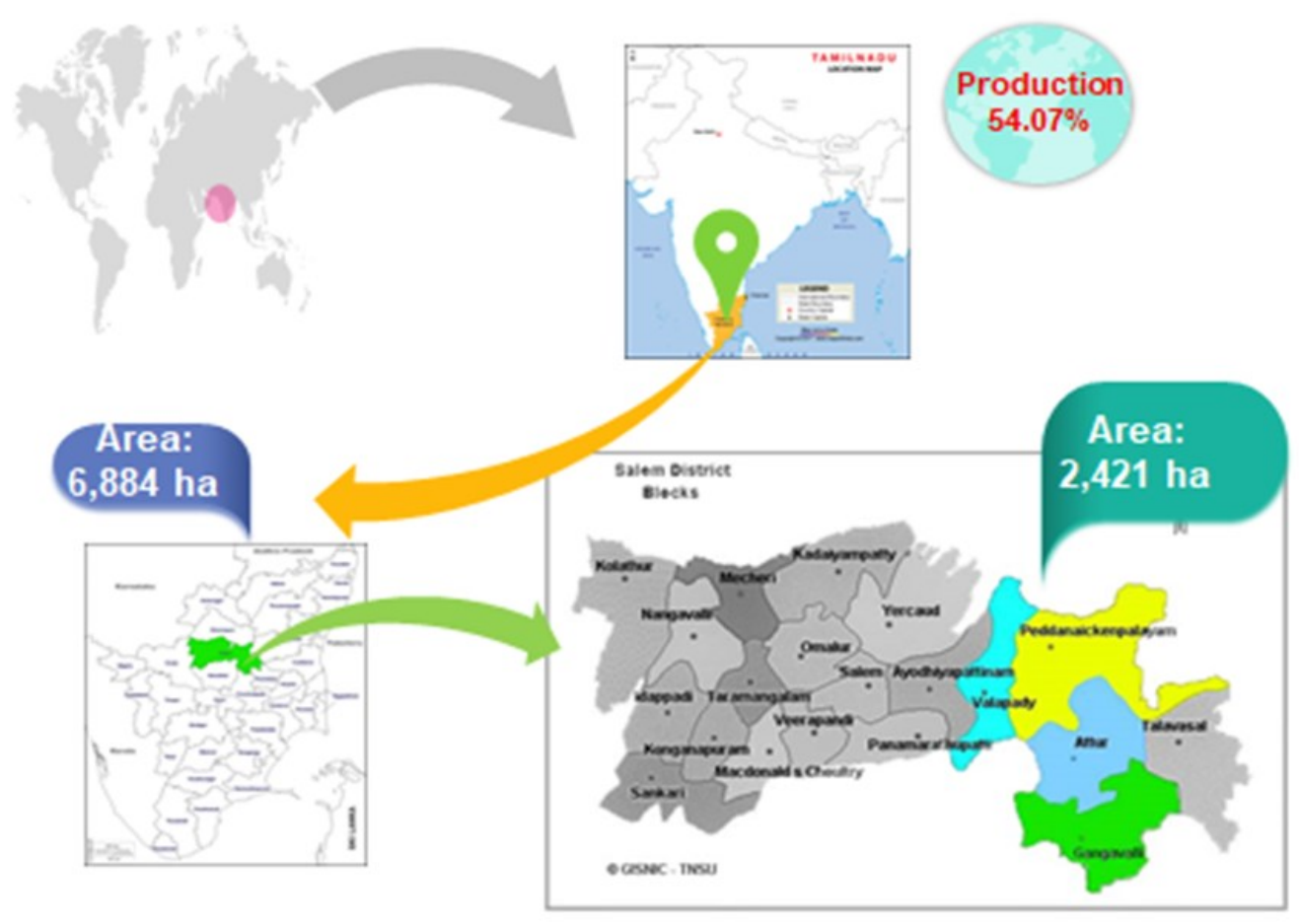

Fig. 1. Map showing the study area of Salem district in Tamil Nadu.

Table 1. Distribution of areca nut growers in the selected blocks.

\begin{tabular}{llcc}
\hline District & Blocks & Number of areca nut growers & No. of respondents selected \\
\hline \multirow{4}{*}{ Salem } & Peddanackenpalayam & 1050 & 52 \\
& Valapady & 715 & 36 \\
& Gengavalli & 420 & 21 \\
& Attur & 220 & 11 \\
& Total & 2405 & 120 \\
\hline
\end{tabular}

Source: Assistant Director of Horticulture office Peddanackenpalayam, Valapady, Gengavalli, Attur 
among the advisory committee members to frame the interview schedule. Data was collected with the help of a well-structured interview schedule and pre-tested in a non-sampling area. The data gathered were quantified and tabulated for statistical analysis. The Percentage analyses were used for analysis and interpretation of data.

\section{RESULTS AND DISCUSSION}

In this article, knowledge denotes the respondent's level of understanding of improved plant protection technologies in the areca nut cultivation. To measure respondents' knowledge level, they were asked straight questions regarding symptoms and management practices of plant protection technologies.

\section{Overall knowledge level on plant protection technologies}

The overall knowledge level of respondents is important to know the understandability of respondents in the view of recommended plant protection technologies. The dichotomized responses are analyzed by cumulative frequency method to categorize their knowledge level into low, medium and high category. Fig. 2 shows that most of the respondents $(80.00$ per cent) had a knowledge level of medium to a high level of knowledge on the recommended plant protection technologies in areca nut cultivation. This knowledge level of the respondents is due to the majority of the respondents had a medium to a high level of information seeking behaviour and social participation (Jaganathan and Nagaraja, 2015 and Jergin et al., 2018).

\section{Knowledge on symptoms and control measure of pest attack}

The present study inferred from Table 2 that 93.33 and 57.50 per cent of respondents had knowledge of the attack of mite's infestation and control measure for a mite infestation, respectively (Vinayak, 2014 and Jergin et al., 2018). Half of the respondents (50.83 per cent) had knowledge of spindle bug infestation and 31.67 per cent of them had knowledge of the control measure on spindle bug infestation. The majority of the respondents (90.83 per cent) had knowledge on the symptoms of inflorescence caterpillar and slightly more than half of the respondents (52.50 per cent) had knowledge on the control measure of inflorescence caterpillar (Lakshmisha, 2000). Most of the respondents (71.67 per cent) had knowledge of symptoms of nematode

Table 2. Distribution of respondents on the knowledge level of recommended practices of symptoms of pest attack and management practices in areca nut.

\begin{tabular}{llll}
\hline I & \multicolumn{1}{c}{ Knowledge on symptoms and control measure of pest attack } & \\
\hline S.no & Technology & Number & Per cent \\
\hline 1 & Symptoms of mite infestation & 112 & 93.33 \\
2 & Control measure for mite & 69 & 57.50 \\
3 & Symptoms of spindle bug infestation & 61 & 50.83 \\
4 & Control measure for spindle bug & 38 & 31.67 \\
5 & Symptoms of Inflorescence caterpillar infestation & 109 & 90.83 \\
6 & Control measure for Inflorescence caterpillar & 63 & 52.50 \\
7 & Symptoms of Nematode infestation & 86 & 71.67 \\
8 & Control measure for Nematode & 61 & 50.83 \\
9 & Symptoms of scale infestation & 87 & 72.50 \\
10 & Control measure for scale & 53 & 44.17 \\
11 & Symptoms of mealy bug infestation & 43 & 35.83 \\
12 & Control measure for Mealy bug & 19 & 15.83 \\
13 & Symptoms of areca nut borer infestation & 101 & 84.17 \\
14 & Control measure for areca nut borer & 38 & 31.67 \\
15 & Symptoms of snails infestation & 46 & 38.33 \\
16 & Control measure for snails & 3 & 2.50 \\
17 & Symptoms of root grub infestation & 120 & 100.00 \\
18 & Control measure for root grub & 116 & 96.67 \\
19 & Symptoms of pentatomid bug infestation & 41 & 34.17 \\
20 & Control measure for pentatomid bug & 21 & 17.50 \\
\hline
\end{tabular}




\begin{tabular}{|c|c|c|c|}
\hline \multicolumn{1}{|c|}{} & \multicolumn{3}{c|}{} \\
\cline { 2 - 4 } & & & \\
\hline
\end{tabular}

Fig. 2. Overall knowledge level of respondents on plant protection technologies.

attack and half of the respondents (50.83 per cent) had knowledge on control measure on nematode infestation. Regarding scale attack, 72.50 and 44.17 per cent of respondents had knowledge on symptom on scale attack and control measure respectively. In mealybug pest, 35.83 and 15.83 per cent of respondents had knowledge on mealy bug infestation and control measure. The areca nut borer infestation and control measure was known by 84.17 and 31.67 per cent of respondents. The knowledge on snail infestation and control measure was by 38.33 and 2.50 per cent respondents only (Sajeev et al., 2018). The root grub infestation in areca nut cultivation was known by cent percent of respondents and management practices by 96.67 per cent of respondents, respectively. The Pentatomid bug infestation and control measure knowledge was known by 34.17 and 17.50 per cent of respondents respectively (Babanna, 2002).

\section{Knowledge of disease attack and control measure}

It was observed from the above table 3 that 70.83 per cent of respondents had knowledge of the bud rot disease and 23.33 per cent of respondents had knowledge of bud rot disease management (Sajeev et al., 2018). Cent per cent of the farmers had knowledge of the foot rot symptoms and 97.50 per cent of them had knowledge on the control measure of foot rot disease (Badhe and Tambat, 2009). The yellow leaf disease symptoms were known by cent percent of respondents and 98.33 per cent of respondents known management practices of yellow leaf disease. Regarding the leaf spot disease, 95.00 and 43.33 per cent of farmers had knowledge of the leaf spot symptoms and control measures. Half of the respondents had knowledge of the inflorescence dieback symptoms (50.83 per cent) and management practices (50.00 per cent), respectively. Half of the respondents (50.00 per cent) had knowledge of bacterial leaf stripe symptoms but only 11.67 per cent of respondents had knowledge of bacterial leaf stripe management (Nagappa et al., 2016).

\section{Knowledge on disorders and management practices}

Table 4 reveals that the nut crack disorder symptoms and management practices knowledge was known by 94.17 and 25.84 per cent of respondents, respectively. Cent per cent of respondents had knowledge of stem breaking symptoms and 99.17 per cent of them had knowledge of stem breaking management practices (Aneani et al., 2013 and Bellary et al., 2010). The band/

Table 3. Distribution of respondents on knowledge level of recommended practices of symptoms of disease attack and management practices in areca nut.

\begin{tabular}{clll}
\hline II & \multicolumn{1}{c}{ Knowledge on disease attack and control measure } & Per cent \\
\hline S.no & Technology & Number & 70.83 \\
\hline 1 & Symptoms of bud rot/mahali & 85 & 23.33 \\
2 & Control measure for bud rot/mahali & 28 & 100.00 \\
3 & Symptoms of foot rot/anabe & 120 & 97.50 \\
4 & Control measure for foot rot/anabe & 117 & 100.00 \\
5 & Symptoms of yellow leaf disease & 120 & 98.33 \\
6 & Control measure for yellow leaf disease & 118 & 95.00 \\
7 & Symptoms of leaf spot & 114 & 43.33 \\
8 & Control measure for leaf spot & 52 & 50.83 \\
9 & Symptoms of inflorescence dieback & 61 & 50.00 \\
10. & Control measure for inflorescence dieback & 60 & 50.00 \\
11. & Symptoms of bacterial leaf stripe & 60 & 11.67 \\
12. & Control measure for bacterial leaf stripe & 14 & \\
\hline
\end{tabular}


Mohanraj, V. et al. / J. Appl. \& Nat. Sci. 13 (SI), 105 - 109 (2021)

Table 4. Distribution of respondents on knowledge level of recommended practices of symptoms of disorders and management practices in areca nut.

\begin{tabular}{llll}
\hline III & \multicolumn{3}{c}{ Knowledge on disorders and management practices } \\
\hline S.no & Technology & Number & Per cent \\
\hline 1 & Symptoms of nut crack & 113 & 94.17 \\
2 & Control measure for nut crack & 31 & 25.83 \\
3 & Symptoms of Stem breaking & 120 & 100.00 \\
4 & Control measure for Stem breaking & 119 & 99.17 \\
5 & Symptoms of Band/Hidimundige & 98 & 81.67 \\
6 & Control measure for Band/Hidimundige & 100 & 83.33 \\
\hline
\end{tabular}

hidimudinge symptoms and management practices were known by 81.67 and 83.33 per cent of respondents, respectively.

\section{Conclusion}

It was concluded that the majority of the farmers in Salem district, Tamilnadu state had knowledge of the pest symptoms on mite infestation, caterpillar infestation and root grub infestations. In disease symptoms, cent per cent of respondents had knowledge on the foot rot and leaf disease followed by disorders on stem breaking and band. The farmers had more knowledge on the pest attack, disease symptoms and disorders than control measure. This level of knowledge on the plant protection technologies was influenced by the medium to high level of information seeking behavior of the respondents. Future trainings are also needed from the state departments to enhance the improved package of practices to the farmers on plant protection measures.

\section{ACKNOWLEDGEMENTS}

I feel great pride and privilege in expressing my profound sense of gratitude and infinite indebtedness to my esteemed chairman of my advisory committee Dr. $R$. Velusamy and express my sincere thanks and gracious faithfulness the members of my advisory committee. I wish to wholeheartedly express thanks to my beloved parent.

\section{Conflict of interest}

The authors declare that they have no conflict of interest.

\section{REFERENCES}

1. Ananth, M. K. (2016). Co-operative marketing to help areca nut farmers in Salem. The Hindu, p. 2.

2. Aneani, F. \& Ofori-Frimpong, K. (2013). An analysis of yield gap and some factors of cocoa (Theobroma cacao) yields in Ghana. Sustainable Agriculture Research, 2 (526 -2016-37857).

3. Babanna, T. (2002). Information source consultancy and training needs of farmers in areca nut cultivation under Tungabhadra command area in Shimoga district. M.Sc. (Ag.) Thesis, University of Agricultural Science, Bangalore.

4. Badhe, M. M. \& Tambat, R. G. (2009). Problems experienced by the areca nut growers in areca nut cultivation. Asian Sciences, 4(1 \& 2), 45-46.

5. Bellary, S. \& Patil, V. (2010). Agronomic practices adopted by Areca nut farmers in Koppa and Sringeri taluks. Karnataka Journal of Agricultural Sciences, 18(3), 791793.

6. Food and Agriculture Organization (2017). FAO Statistical Year book 2017. Rome 2017: Food and agriculture organization of the United Nations.

7. Jaganathan, D. \& Nagaraja, N. (2015). Perception of farmers about areca nut based multispecies cropping system. Indian Research Journal of Extension Education, 15(2), 49-54.

8. Jergin, J., Somasundaram, S. \& Velusamy, R. (2018). Personal and socio-psychological characteristics of rubber growers in Kanyakumari district of Tamil Nadu. Indian Journal of Positive Psychology, 9 (2), 225-228.

9. Lakshmisha (2000). Impact of cashew demonstration knowledge and adoption and yield levels of farmers in Dakshina Kannada district. (M.Sc. (Ag.) Thesis), University of Agricultural Science, Bangalore.

10. Nagappa, D., Sukanya, T. \& Mamatha, B. (2016). Problems experienced by farmers in areca nut cultivation. Asian Journal of Horticulture, 11(2), 301-305.

11. Sajeev, M. V. \& Saroj, P. L. (2018). Socio-economic determinants and adoption of pest management practices in cashew farming: A study in Dakshina Kannada, Karnataka. Journal of Plantation Crops, 46(1), 66-73. doi:10.25081/jpc.2018.v46.i1.3543.

12. Vinayak, N. (2014). A Study on knowledge, adoption and economic performance of areca nut growers in North Kanara District of Karnataka. (M.Sc (Ag.) Thesis), University of Agricultural Sciences, Bangalore.

13. Krishisewa (2017). Retrieved from https://www.kris hisewa.com/articles/production-technology/61-areca nut.html 